\title{
United States Foreign Policy and the Middle East
}

\author{
Atallah S. Al Sarhan \\ Department of Political Science, Clark Atlanta University, Atlanta, GA, USA \\ Email: atallah.alsarhan@students.cau.edu
}

How to cite this paper: Al Sarhan, A. S. (2017). United States Foreign Policy and the Middle East. Open Journal of Political Science, 7, 454-472.

https://doi.org/10.4236/ojps.2017.74036

Received: June 4, 2017

Accepted: August 26, 2017

Published: September 11, 2017

Copyright (C) 2017 by author and Scientific Research Publishing Inc. This work is licensed under the Creative Commons Attribution International License (CC BY 4.0).

http://creativecommons.org/licenses/by/4.0/

\begin{abstract}
The Middle East has been a central focus of the United States' foreign policy. The purpose of the current research is to shed light on the United States' economic and political presence in the Middle East region before and after World War I and after World War II to understand how United States' presence has developed in the region and what motives were behind its presence. This is accomplished by exploring broad economic, strategic, and political motives of the United States. Specifically, the article explores the United States' primary interests in the Middle East including securing strategic access to oil in the Gulf region, supporting and protecting Israel's sovereignty, maintaining the United States' military bases, defending client-states and friendly regimes, and resisting Islamic movements and terrorist groups.
\end{abstract}

\section{Keywords}

U.S. Foreign Policy, Middle East, National Security, Gulf Region, Sovereignty, Military Bases, Client-States, Friendly Regimes, Islamic Movements

\section{Introduction}

The Middle East has continued to garner the primary attention of the United States' foreign policy since World War II, and this paper seeks to explore reasons for this phenomenon, which, to date, has received little research attention. The significance of the Middle East area has increased rapidly since WWll primarily due to economic, strategic, and political factors. Culturally, the region has numerous similarities with the West, dating back to the time of the Crusades in the Middle Ages and continuing through modern history with the efforts of the Western missionaries and their educational activities. The Middle East consists of portions of three continents: Europe, Asia, and Africa. The land possesses vital resources including oil and waterways (Lenczowski, 1984). 
The term "Middle East" is relatively new. In 1902, the name appeared in a series of articles in a British daily newspaper: The Times. After World War II, the term "Middle East" became widely accepted, especially in academic institutions and government agencies (Peretz, 1968). The geographical boundaries of Middle East vary, and it is also called the Near East or Southwest Asia. In academia, Middle East refers to the Arab states of Asia; the Arab states of North Africa; Israel; and the non-Arab states of Afghanistan, Iran, Pakistan, and Turkey (Surratt, 2000).

In this article, the United States' presence in the Middle East has been divided into three distinct periods: the first ends in 1914; the second begins after 1919, and the third begins after 1945 .

\section{The United States' Foreign Policy toward the Middle East before World War I}

American trade with the Middle East dates back more than two hundred years. In fact, commercial contacts between Smyrna (an ancient city in Turkey) and Boston began as early as 1767 , when Smyrna products (most notably figs) appeared in America. Thereafter, an American trading house was established in Smyrna in 1811, laying the groundwork for the first American Ottoman treaty that was signed on May 7, 1831 (Howard, 1974).

American religious groups, especially Presbyterians, conducted multiple missions in the Middle East that were not only religious, but charitable and medical as well. The American missionaries in the Middle East appeared as early as 1820, when the American Board of Commissioners for Foreign Missions established the first American religious mission in the region. The American missionaries and philanthropic organizations began going to the Middle East to carry out their ministries to the population.

These missionaries, however, were unable to convert many Muslims or Jews to Christianity, but instead influenced and modernized education in the region; establishing outstanding institutions such as Robert College in Turkey founded in1863, Syrian Protestant College, later renamed American University of Beirut (AUB) founded in1866, Istanbul Women's College founded in 1871, and The American University of Cairo founded in1919 (Howard, 1974). The AUB "became (at least in some fields) the most outstanding institution of higher learning in the Middle East. By the end of the nineteenth century, AUB was a highly influential center for the emergence and promotion of Arab nationalism." (Crabb, Jr., 1983, p. 399). Contributions to higher education made America popular in the eyes of the local populace, and the lack of the American political motivation strengthened the general goodwill toward American democracy (Lenczowski, 1980).

In light of the foregoing discussion, it is clear that before World War I the United States' contact with the Middle East region was limited to commercial, missionary, and educational activities. The demise of the Ottoman Empire at the end of World War I placed the entire area of the Middle East under European 
influence. Egypt, Iraq, Palestine, Sudan, and Transjordan were under the British mandate, while the North African states, Lebanon, and Syria were under the French mandate. The Gulf region was under the British influence as well. In this context, it is important to point out that, during the period between the two world wars, some states in the region achieved a nominal independence with the Europeans maintaining only some influences until the end of World War II. The European colonialism significantly delayed the Arab dreams to establish their own independence under one unified nation-state. In contrast, the United States showed little interest in international affairs in general during and after World War I. This was especially the case in the Middle East region, as 'isolationism' was the predominant feature of the United States' foreign policy until Japan bombed Pearl Harbor on December 7, 1941.

\section{The United States' Foreign Policy toward the Middle East after World War I}

During and after World War I, the American political thoughts, ideas, and principles were appealing to the Middle East. In addition, President Woodrow Wilson's concept of "self-determination" of nations was essential and supportive to the rights of people to decide to have their own political destiny. These concepts were very attractive to the Arabs nationalists' dreams to attain independence. Moreover, the Wilsonian ideas "...provided a stimulus to Arab nationalism in the years ahead. Until the creation of the State of Israel (in 1948), the United States enjoyed widespread prestige and admiration in the Arab world." (Crabb, Jr., 1983, p. 400).

In 1917, President Woodrow Wilson's administration endorsed a letter that was sent from the British Foreign Secretary, Arthur Balfour, to Lord Lionel Rothschild, a British Zionist leader, to establish a "national home" for Jewish people in Palestine. Then, in 1922, a joint resolution of Congress voted unopposed for this "Mandate for Palestine". This mandate validated Jewish claims to settle Palestine anywhere from the Jordan River to the Mediterranean Sea. Nearly two months later, on September 21, 1922, President Warren G. Harding signed the joint resolution to confirm the establishment of a Jewish national homeland in Palestine (Hertz, 2008).

In the aftermath of World War I, even though the Middle East region was under heavy European influence, American contacts, especially petroleum companies, with the region increased steadily. While American companies gained only a partial interest in businesses in Iran and Kuwait, they attained full control in Saudi Arabia and the Bahrain Island (Pratt, 1972).

The period between the two world wars shows that the United States remained only slightly involved in the Middle Eastern affairs from a political standpoint; on the other hand, the United States had established multiple economic contacts within the Middle East region. The American petroleum companies negotiated a number of concessions in Iran, Kuwait, Saudi Arabia, and Bahrain. During World War II, the United States' presence in the Middle East in- 
creased. In addition, the United States government paid closer attention to the region's significant oil reserve and began to reevaluate its importance to American and Allied security interests but, "It was not until the end of the [Second World] war that the area came to assume any real significance in U.S. foreign policy." (Ismael, 1986, pp. 135-136).

\section{The United States' Foreign Policy toward the Middle East after World War II}

The United States' political presence in the Middle East did not intensify until the end of World War II. Prior to that, three indirect occurrences may be cited in this regard: "1) Iran was used as a transit route for the sending of Lend-Lease supplies to the Soviet Union from 1941-1945; 2) Aramco, the Arabian-American Oil Company, was established in Saudi Arabia in 1938; 3) America influenced the Arab nationalist movement in the early 1920s through its domestic ideals." (Jones, Jr., 1973, p. 184). Since that time, influenced by shifts in power, interest in oil, and the Palestine Question, the United States has consistently focused their attention on the Middle East.

At the end of World War II, a new balance of power prevailed in the international arena. The United States and the Soviet Union emerged as the only two superpowers in the international system. The main European powers (Britain and France) faced substantial economic difficulties and were no longer capable of playing their traditional leading roles in the Middle East. In the early 1940s, President Roosevelt and his administration initially expected that Britain would remain the security chief in the region. However, by the spring of 1944 observers reported, "Soviet policy in the Arab world appears to be aimed at the reduction of British influence in that area and the acquisition of the balance of power." Then, on May 8, 1945, State Department personnel determined that Britain was unable to maintain the Soviet Union and realized the United States might have to take charge of "fostering the economic advancement of the Middle East people" and "facilitating freedom from external interference and exploitation." (Little, 2002, pp. 119-120).

After World War II, the Kremlin wanted to spread its influence along Russia's southern border. In 1941, Josef Stalin ordered Soviet troops into Iran and increased diplomatic pressure on Turkey, which had previously refused the "Red Navy" to cross the Dardanelles (the channels between the Black Sea and the Mediterranean). By the fall of 1945, the United States' policymakers expected the worst. "The British publicly admit that they are no longer able to keep the Middle East in order without ... [US] help." The State Department cautioned the President that "Soviet Russia is showing a marked interest in the area." If the United States did not respond "firmly and adequately," another world war might result. Washington, responded by issuing the Truman Doctrine in 1947 that indicated that the United States would take over Britain's commitment to Greece and Turkey." (Little, 2002, pp. 119-120).

In the mid-1950s, concern regarding possible Soviet expansion in the Middle 
East region motivated Secretary of State, John Foster Dulles, to seek out allies in the states closest to the Soviet Union (Lenczowski, 1984). In February 1955, the United States' efforts resulted in the formation of the Baghdad Pact Organization (also known as the Middle East Treaty Organization [METO]). METO was formed by Iraq, Turkey, Britain, Pakistan, and Iran. The main purpose of METO was to limit possible Soviet Union expansion in the Middle East region.

After ten years of Anglo-Arab confrontations, the United States' policymakers presented the Eisenhower Doctrine, making Washington a high-ranking member of the Anglo-American Association in 1957 (Little, 2002). The Eisenhower Doctrine was established in response to the 1956 Suez War, the Soviet Union's infiltration of the Arab states, and to limit Nasser's expansive pan-Arabism. Following the 1958 Lebanon crisis, Baghdad Pact members, except Iraq, endorsed American intervention in Lebanon. In 1959, Iraq withdrew from METO resulting in METO to be renamed as the Central Treaty Organization (CENTO), and its headquarters to be moved from Baghdad to Ankara. The United States' support to CENTO continued as a non-signatory associate until it completely dissolved in 1979 ("The Baghdad Pact (1955) and the Central Treaty Organization (CENTO)," 2009).

Through the 1960's, Britain continued to experience financial difficulties and was eventually forced to give up its remaining imperial stations in the Arabian Peninsula and the Gulf region. It was at this time that American officials began moving toward what would come to be known as the Nixon Doctrine, which appointed countries in the region, including Iran and Saudi Arabia, to join in the opposition against the Soviet Union. However, when the appointed Middle Eastern countries proved they were ultimately unable to fill this role effectively, Jimmy Carter created his own doctrine and "informed the world in January 1980 that the United States had vital security interests in the Middle East for which it was willing to fight, whether it had dependable partners or not." (Little, 2002, pp. 119-120).

It is important to point out that since the beginning of the Cold War, the United States had developed several policies, strategies, and tactics to limit possible Soviet expansion in the world and in the Middle East region in particular. Containment, détente, and deterrence were among the most notable policies during the context of the Cold War. In the early 1990s, the Cold War era came to an end, and the Soviet Union threat to the region ended, with the impact of international communism at its lowest in decades. As a result of the Cold War, the United States remained as the sole dominant superpower in the post-Cold War era. Hegemony, leadership, primacy, and military power clearly marked American foreign policy in international affairs in the late twentieth century and early twenty-first century.

The goal of ensuring secure access to oil resources in the Middle East region, especially in the Arab oil-rich states and the Palestine Question, motivated the United States' presence in the region since early in the twentieth century. These incentives just scratched the surface of what would be a much deeper involve- 
ment in the Middle East from the fall of the Soviet Union to the present.

In sum, the Middle East has continued to be a primary attention of the United States' foreign policy since World War II. Notably, three primary issues focused the United States' attention on the Middle East, including security concerns, interests in oil reserves, and the Palestine Question. Indeed, these factors are also inter-related as security and stability of the Middle East is important to ensure reaching oil to North America, Europe, and Japan and to ensure Israel's sovereignty.

\section{The United States' Foreign Policy Interests in the Middle East}

Beginning with the end of World War II and continuing in response to a variety of economic and safety concerns, the United States' interests in the Middle East grew exponentially, and this involvement continues today. American interests in the region include: securing strategic access to oil in the Gulf region; supporting and protecting Israel's sovereignty; maintaining the United States' military bases, especially those in the Gulf states; defending client-states and friendly regimes; and resisting Islamic movements and terrorist groups such as Hamas, Al-Qaeda, Islamic State of Iraq and Syria (ISIS), and many others that might affect American and their allies' interests in the region.

\subsection{Securing Strategic Access to Oil in the Gulf Region}

The primary interest of the United States in the Middle East region is to assure American access to oil. Oil, however, was not considered significant until the end of the nineteenth century. The First Industrial Revolution that began in the last decades of the eighteenth century was fueled by water power and then by coal. The Second Industrial Revolution was driven by the surge of readily available and comparatively cheap oil that became a growing necessity in the world's rapidly expanding petroleum-based economies. This spurred an insatiable thirst for fresh supplies of crude and new markets in which to expand. In the late nineteenth century and early twentieth century, the petroleum industry and the consumption of oil-based products developed rapidly across the world and especially in Europe and North America. At the time, the main sources of oil were Russia, the United States, Mexico, and Romania (Gelvin, 2005).

In this context, it should be noted that in the early twentieth century, the petroleum industries flourished all over the world, but most especially in Europe and North America. During World War I, major world powers began to prioritize oil as a vital military asset; modern warfare caused a constant need for oil and its subsidiary petroleum-based products which were a necessity for ships, airplanes, tanks, submarines, and the lubrication of modern rifles. This heavy use of oil during World War I created a severe shortage in 1917-1918 (Paul, 2002).

Following World War I, several Western companies gained mutual concession in the Middle East, especially in Iran, Bahrain, Kuwait, and Saudi Arabia. The idea behind these mutual concessions was to negotiate solutions to incom- 
patible political and business agendas and to make entrepreneurial explorations safer. At the close of the Second World War, the United States government became wary about cutbacks in oil production and the possible economic hiccups that would stem from a fuel shortage. To prevent a fuel shortage, the United States made economic demands for concessions with multiple Middle Eastern countries. This requirement started in the pre-war years with concessions in Bahrain (1929), Kuwait (1934), and Saudi Arabia (1947). These concessions were shared by multiple oil companies (Rustow, 1982).

In 1948, following American demands, several companies were developed to exploit these concessions. The Arabian American Oil Company (ARAMCO) was created by Esso (now Exxon), Texaco, Standard Oil of California (SoCal), and Mobil all came into existence to develop the Saudi concessions. These companies soon surveyed and developed large production fields that allowed them to harvest massive profits from low-cost oil that would be used to rebuild the economies of Europe and Japan that had been destroyed during World War II. The boom eventually brought this cheap oil to United States shores and stimulated the growth of the post-war American economy, which reiterated the desire for more United States companies to seek concessions in Kuwait, Iran, and other oil producers in the region (Diller, 1991).

Meanwhile, as the development of the Middle Eastern concessions increased, the United States oil production began to decrease in ratio to its increased consumption. This grew to as much as $30 \%$ of the world's total consumption of crude oil with only an estimated $6 \%$ of the world's reserves (Iskandar, 1974).

Following World War II, the United States began looking for alternative sources of oil abroad to meet its own future demands. The Middle East was very attractive to both the United States government and American petroleum companies due to its proven long-term oil reserves. Arab oil reserves were shown to potentially have much more than the originally estimated $60 \%$ of the world oil reserves. In fact, Saudi Arabia, Iraq, Kuwait, and Abu Dhabi possessed more than 50\% of the known reserves amongst themselves alone (Iskandar, 1974). To attest to this high-quality Middle Eastern oil was known to flow freely of its own pressure. This circumstance allowed for much cheaper production costs; the Middle East per production barrel ranged between $\$ 0.10$ and $\$ 0.22$ cents in comparison to $\$ 0.39$ cents in Venezuela, and as much as $\$ 1.51$ per barrel in the United States. This is a considerable difference when it comes to the bottom line (Rustow, 1982).

James L. Gelvin, in his book, The Modern Middle East: A History, indicates that among the most notable objectives of the United States in the Middle East region is to assure Western access to oil. The reasons for this are twofold: first, economic reasons are primary, and second, the strategic policy is dictated by the fact that the United States must supplement its domestic output of oil from the Middle Eastern resources. This is demonstrated by the fact that in 1973 as much as a third of the United States' oil imports came from the Middle East just prior 
to the Oil Embargo Crisis. Even today the amount of oil remains at one-fifth of American imports. From a strategic perspective, the post-war economic recoveries of Europe and Japan were fueled by cheap Middle Eastern oil. Ever since the Oil Embargo Crisis, American policy has viewed oil as a strategic resource, as does much of the world. In fact, more than 40 years later, even Europe gets more than a third of its oil from the Middle East, and Japan gets nearly $80 \%$ of its oil from Middle Eastern trade partners (Gelvin, 2005).

Throughout the 1973 Arab-Israeli War, Arab members of the Organization of the Petroleum Exporting Countries (OPEC) led an embargo against the United States in response to the decision to re-supply the Israeli military. The embargo also applied to other countries that braced Israel including South Africa, the Netherlands, and Portugal. Petroleum exports were barred, and manufacturing reductions were made, straining the United States' economy that was extremely reliant on foreign oil.

\subsection{Supporting and Protecting Israel's Sovereignty}

The second interest of the United States in the Middle East region is to safeguard the state of Israel and to ensure its stability in the often troubled region. In fact, maintaining a strong Israel in the Middle East solidifies American national security interests there. This perspective has dominated American foreign policy since the mid-twentieth century and continues to shape the current policy.

The historical land of Palestine was under the authority of the Ottoman Empire until the end of World War I, when Britain assumed control of Palestine as a mandate under the League of Nations. During World War I (1914-1918), secret agreements were made between the British government and the British Zionist community leaders, leading to the Balfour Declaration and establishing a "national home" for the Jewish people in Palestine.

Before Britain announced the Balfour Declaration, the British government tried to persuade President Woodrow Wilson to endorse the proposed statement (Balfour Declaration). Initially, Wilson was reluctant to do so as he thought that such a declaration would worsen US-Ottoman relations. Finally, under pressure by Louis D. Brandeis, an influential Zionist leader in America and Wilson's close friend and confident, President Wilson showed sympathy with the Balfour Declaration. The British saw Wilson's approval of the draft declaration as de facto support for a Jewish homeland in Palestine and support for British control of this area as protectorate following the war. This tacit support went against Wilson's agenda of self-determination put forth in his Fourteen Points and undermined the Palestinian Arab's right to self-determination, but this would not stop the United States from adopting the Balfour Declaration (Mulhall, CSP., 1995). In September 1922, Congress adopted a resolution approving the Balfour Declaration, and thus formalized the United States' foreign policy toward Palestine. From then on, the United States continued to support Jewish migration to Palestine.

Then in late 1947, the Truman administration supported the "Partition Plan" 
of the United Nations Special Committee on Palestine (UNSCOP) that proposed partitioning Palestine into Arab and Jewish states. On November 29, 1947, the "Partition Plan" was approved by the United Nations General Assembly. After the "Partition Plan" was passed, the Truman administration continued to promote Jewish emigration to Palestine and the establishment of an egalitarian commonwealth. Congress adopted a resolution in December 1947 for this explicit purpose. On May 14, 1948, the State of Israel announced its independence.

From that point on, the historical land of Palestine has been known as Israel. Minutes after Israel declared its independence, the United States became the first country to recognize their independence. Shortly after that, the Soviet Union and other countries also recognized the independence of the Jewish state. Following the announcement of the independence of Israel, the first Arab-Israeli War of 1948 began, and Egypt led Iraq, Lebanon, Syria, Transjordan, and Saudi Arabia in launching attacks on the territory in support of the Arab Palestinians. As a result of this war, Israel acquired land that was previously given to Palestinian Arabs according to the November 29, 1947, United Nations General Assembly Resolution 181 ("The Arab-Israeli War of 1948," n.d.). Continuing their policy of supporting Jewish immigration to Palestine, following the Arab-Israeli War of 1948, the Truman administration explicitly facilitated this process. Truman's policies reveal his sympathy for Jewish aims in Palestine. After the war, a small number of Palestinian Arabs remained in Israel while most of them retreated to the West Bank and the Gaza Strip that remained under Jordanian and Egyptian control respectively until the Six-Day War of 1967. Hundreds of thousands of Palestinian Arabs were exiled and permanently moved out to the United Nations' refugee camps in surrounding Arab states. As a result, many Arab officers felt they had been "stabbed in the back" by their governments, who had entered the war unprepared and without the fortitude to fight a determined foe. They also criticized their governments for not developing the military infrastructure necessary to claim victory on the battlefield (Gelvin, 2005).

Following the Six-Day War of 1967, the United States voted and endorsed the United Nations Security Council Resolution 242. The succeeding American presidents have sponsored some initiatives, agreements, and treaties with some Arab states and the Palestine Liberation Organization (PLO) to assure the sustainability of Israel. The most preeminent arrangements are the Egyptian-Israeli Peace Treaty of March 26, 1979; Declaration of Principles on Interim Self-Government Arrangements (Oslo I) of September 13, 1993; The Jordan-Israel Peace Treaty of October 26, 1994; and The Israeli-Palestinian Interim Agreement (Oslo II) of September 28, 1995.

As noted earlier, it is clear that the US-Israeli relationship dates back decades and includes the provision of $\$ 115$ billion of military, economic, and diplomatic support since 1949. From the onset of the Cold War, Israel is viewed as a close ally of the United States in a turbulent Middle East region and critical to American national security interests. Since the height of the Cold War, Israel has served as a safeguard against Soviet communism and Arab nationalism in the 
Middle East. Despite many political changes, this logic remains true to this day, with Israel serving as a protection against political Islam and other extremists. This policy has also served to reduce the propagation of Weapons of Mass Destruction (WMD) in the region by destroying Iraq and Syria's nuclear programs (Eisenstadt \& Pollock, 2012).

\subsection{Maintaining the United States' Military Bases}

The third interest of the United States in the Middle East region is maintaining its military bases, especially those in the Arab oil-rich states along trade routes and pressure points that will allow the United States' policy to, directly and indirectly, influence the entire region. The United States' military bases can be defined as military places that are used for training purposes, preparation, and stocking of military equipment for American military assistance or operations throughout the world. These military bases are not open to the public and usually, take different shapes according to the military purpose for which they were established. The United States' military bases can be classified into four primary categories: Air Force; Army or Land; Navy; and Communication and/or Spy (Dufour, 2007).

Before World War II, the number of United States' military bases overseas was limited. However, with the onset of the Cold War, the number of military bases and military installations increased rapidly around the world. According to Alexander Cooley's description of the United States' Department of Defense's 2006 Base Structure Report, "the United States officially maintains 766 military installations overseas and another 77 in non-continental U.S. territories. Fifteen of these facilities were estimated to be worth more than $\$ 1.6$ billion each, whereas an additional 19 were valued at between $\$ 862$ million and $\$ 1.6$ billion." (Cooley, 2008, p. 5).

Prior to 1980, the United States maintained a minimal military presence in the Middle East. In the early 1970s, the United States concluded an agreement with Bahrain for intermittent use of its naval facilities by the United States Navy for a stipend of \$4 million a year. However, following the 1973 Arab-Israeli War, Bahrain, no longer supportive of the American military presence, terminated the lease (Sandars, 2000). Then, the 1979 Iranian Revolution and the 1979 Soviet Union invasion of Afghanistan constituted a substantial threat to America's vital interests in the region, especially considering the location of an estimated $40 \%-70 \%$ of the world's oil reserves. In his 1980 State of the Union address, President Jimmy Carter announced that the United States would defend its interests in the Gulf region from outside force by any means necessary, including military action. In March 1980, Carter ordered the formation of the Rapid Deployment Joint Task Force (RDJTF) ("2015 Index of U.S. Military Strength," n.d.). In order to promote a long-term solution to the region, President Ronald Reagan unified the command structure of the RDJTF and became more involved in its relationship with the region. This act, combined with the creation of the United States Central Command (CENTCOM) on January 1, 1983, established and enhanced 
the command structure to better accommodate its mission in the region ("U.S. Central Command History," n.d.).

The United States CENTCOM Area of Responsibility (AOR) covers the central proximity of the world, the Middle East. It includes countries in the Middle East, North Africa, and Central Asia, most notably Afghanistan, Bahrain, Egypt, Iran, Iraq, Jordan, Kazakhstan, Kuwait, Kyrgyzstan, Lebanon, Oman, Pakistan, Qatar, Saudi Arabia, Syria, Tajikistan, Turkmenistan, United Arab Emirates, Uzbekistan, and Yemen (see Figure 1). The primary mission of the United States CENTCOM is to secure conditions for the region's stability, security, and prosperity by stimulating cooperation between nations, responding to crises, limiting and preventing aggressions, and supporting development and reconstruction ("U.S. Central Command History," n.d.). Through combined military operations, education, and human service, CENTCOM serves to maintain access to facilities in the Middle East as well as to develop relationships with local leaders ("Military: Exercises-Central Command," 2017).

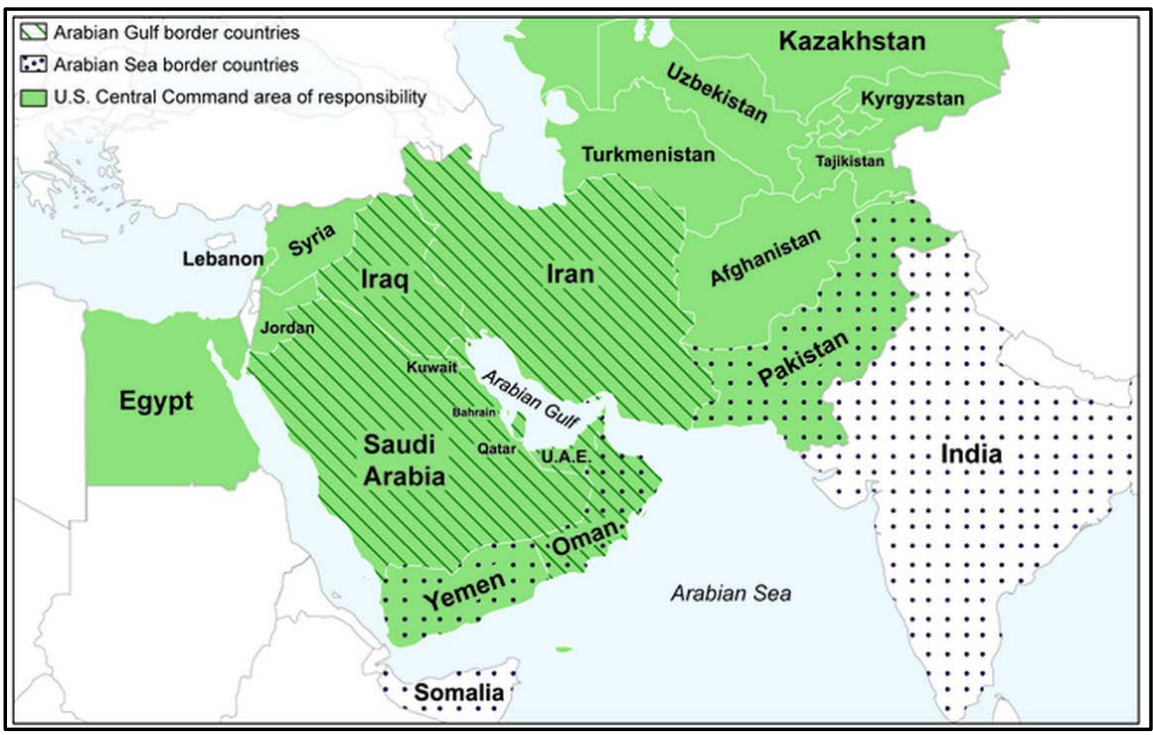

Figure 1. Map of the United States Central Command Area of Responsibility. Retrieved from http://www.gao.gov/products/GAO-15-45.

Four service components and one subordinate unified command make up the United States CENTCOM: the United States Naval Forces, Middle East located in Bahrain, the United States Army Forces, Middle East based in Kuwait, the United States Air Forces, Middle East in Qatar, the United States Marine Forces, Middle East established in Bahrain, and the United States Special Operations Command, Middle East based in Qatar ("2015 Index of U.S. Military Strength," n.d.).

Following the collapse of the Soviet Union in the early 1990s, the Saddam Hussein regime began posing a new and substantial threat to the United States' 
national security interests in the region. After the Iraqi invasion of Kuwait in 1990, the United States began assembling a coalition of more than 30 countries to oust the Iraqi military from Kuwait in January 1991. The United States CENTCOM directed more than 532,000 United States' military personnel that made up the coalition armed forces (a total of more than 737,000), the apex of the United States' deployment in this region. In 1991, there was a Gulf War ceasefire, but there were persistent Iraqi conflicts over the next ten years ("2015 Index of U.S. Military Strength," n.d.).

In the aftermath of the September 11, 2001, terrorist attacks, the United States CENTCOM's AOR was central to the Global War on Terrorism and engaged in operations in Afghanistan, Iraq, the Horn of Africa, and elsewhere in the AOR ("Military: US Central Command (USCENTCOM)," 2016). Specifically, at that time, the George W. Bush administration insisted that the Iraqi regime did not cooperate with the United Nations' arms inspectors to confirm that any WMD were destroyed and that it was supporting terrorism. As a result of these factors, America invaded Iraq in 2003. Initially, 150,000 United States' military personnel were deployed to join personnel from coalition powers. This number increased by 30,000 in 2007, but the United States' forces in Iraq have otherwise typically remained between 100,000 and 150,000. It was not until December of 2011 that the United States officially withdrew its troops, leaving only 150 personnel remaining at the American embassy in Iraq. Since this time, the remaining troops in the Middle East (roughly 35,000 United States' military personnel) are primarily based in the Gulf states ("2015 Index of U.S. Military Strength," n.d.).

In summary, this article shows, it is clear that early United States' military presence in the Middle East was limited before World War II. However, during and after World War II, the United States maintained a minimal military presence in Iran, Iraq, Saudi Arabia, and Bahrain. Following the Iraqi invasion of Kuwait in 1990, the United States intensified its military presence and expanded its military base footprint in the Gulf states. Furthermore, the United States' military presence in the region has helped to guarantee safe access to oil for America and its allies, to ensure stability and security of the friendly regimes, to provide quick response to internal and external crises, to counter radical forces and Islamic extremist groups that might threaten American interests in the region, and, finally, to support the short and long-term strategic foreign policy agendas of the United States.

\subsection{Defending Client-states and Friendly Regimes}

The fourth interest of the United States in the Middle East region is maintaining a close relationship with its "client-states" and friendly regimes. The Dictionary of Government and Politics defines client-state as a "country which depends on another country for such things as defense, trade, etc." (Collin, 1998, p. 50).

The Guide to International Relations and Diplomacy defines client-state as a 
"country that is economically, politically, and/or militarily dependent upon another state.... The relationship is bilateral, and normally beneficial one, with mutual, although different, obligations. The client state... is often militarily powerful but economically weak.... client states during the Cold War were Israel and South Korea for the United States, and Syria, Iraq... for the Soviet Union." (Fry, Goldstein, \& Langhorne, 2002, p. 9).

At the beginning of the Cold War, several Middle Eastern countries were divided into two respective camps. In one camp, countries such as Egypt and Syria supported the Soviet Union and were adopting international communist ideas. In the other camp, countries such as Greece, Turkey, and Israel backed the United States and adopted capitalist ideas and style. Both parties, however, were getting economic, military, and diplomatic support from either Washington or Moscow. In addition, to some extent, a few states were able to use their diplomatic skills to gain support from both parties. Protecting client-states has been essential to the United States' foreign policy for many decades. However, since the United States has expanded its interests overseas, it has used a system of revolving maintenance of particular regimes and has needed to take on additional clients from time to time to affect its interests (Sylvan \& Majeski, 2003).

Following the demise of the world's traditional powers (Ottoman, British, and French) in the Middle East, most newly independent countries in the region faced substantial economic difficulty and were heavily dependent on foreign assistance. During the Cold War rivalry, the United States and the Soviet Union emerged as the chief providers of foreign aid. Both superpowers recognized the importance of the region for their national security interests and thus sought to reinforce their relationships with the countries of the region and build what came to be known as client-states. Division among countries of the area rapidly appeared with some states giving support to the Soviet Union and other states supporting the United States.

In the aftermath of World War II, the United States recognized the Soviet Union's interests in the region and thus sought to deny its possible expansion through several policies including containment, détente, and deterrence; building defensive organizations and alliances such as North Atlantic Treaty Organization (NATO) in 1949, Southeast Asia Treaty Organization (SEATO) in 1954; METO in 1955, and CENTO in 1959; and aggressively pursuing many agreements, accords, and treaties of mutual cooperation and friendship.

Since the early1940s, the United States has pledged to provide economic, military, and protective assistance to several countries in the Middle East to maintain its national security and strategic interests there. Specifically, the following countries became "client-states" of the United States dating back to the mid-1940s: Saudi Arabia (1945), Greece and Turkey (1947), Israel (1948), Iran (1953), Pakistan (1954), Lebanon (1957 and ends in 1975), Jordan (1963), Tunisia (1974), 
Egypt (1976), Kuwait, Bahrain, and Oman (in 1991-1992) (Sylvan \& Majeski, 2003).

The patron-client relationship within the Middle Eastern countries has achieved success in maintaining American and Allied security interests in the region. However, throughout this process, an uneven relationship was fashioned between the United States and the Middle Eastern countries. This uneven patron-client relationship has enabled the United States to gain full access to proven energy supplies. Also, this relationship opened the door for establishing more military bases and installations that consequently have increased the presence of American personnel in the Gulf. Specifically, as previously noted, in 2014, as many as 35,000 United States' military personnel operated in the Middle East; however, precise numbers are not available given the sensitive politics of the region ("2015 Index of U.S. Military Strength," n.d.).

Finally, economic, military, and diplomatic support has been extended to friendly regimes in the Middle East. However, with the onset of the 2010-2011 Arab Spring, the United States' foreign policy changed toward these regimes as the United States decided to support individuals in revolution instead of supporting their regimes. This decision stands in contrast to the United States' previous approach in Tunisia, Egypt, Libya, Syria, Bahrain, and Yemen. This decision has proven to be a double-edged sword that may have created more long-term confusion and chaos to the indigenous population than keeping the previous regimes in power might have done.

\subsection{Resisting Islamic Movements and Terrorist Groups}

The fifth interest of the United States' foreign policy in the Middle East region is countering the Islamic resistance movements and terrorist groups. Following the Soviet Union invasion of Afghanistan in 1979, the United States and its allies condemned the Soviet action against Afghanistan. Then, the United States government developed a number of measures to enforce the Soviets to withdraw their forces. As previously referenced, President Carter, in his State of the Union address on January 23, 1980, said “An attempt by any outside force to gain control of the Persian Gulf region will be regarded as an assault on the vital interests of the United States of America, and such an assault will be repelled by any means necessary, including military force." (Carter, 2001, p. 857).

As a direct result of the Soviet invasion of Afghanistan, the United States, China, and Arab states both openly and subversively supplied money and military assistance through arms and training to the Mujaheddin. The United States itself committed \$4-5 billion during the years 1980-1992. Between the United States, Saudi Arabia, and European and Islamic countries, the Mujaheddin received over $\$ 10$ billion in aid. The majority of this support came to the Afghan rebels in the form of modern lethal weaponry like Stinger Missiles to shoot down Soviet aircraft. Following the insurgency, these same weapons would find their 
way to the next generation of Afghan rebels, who would come to be known as the Taliban (Rashid, 2001).

In the early 1990s, an Afghan faction of Mujaheddin formed the Taliban, Islamic forces who opposed Afghanistan's occupation by the Soviet Union (1979-1989). Covertly, the United States Central Intelligence Agency (CIA) and its Pakistani counterpart, the Inter-Services Intelligence Directorate (ISI) backed this group (Laub, 2014). As a result of this war, the Soviet Union lost billions of dollars and, ultimately, this provoked the economic and political collapse of the Soviet Union in the early 1990s.

Afterward, the Taliban emerged as one of the strongest Islamic factions in Afghanistan during the 1990s. The Taliban ruled Afghanistan from 1996 to 2001. The Taliban regime was isolated and not initially recognized internationally; only Saudi Arabia, the United Arab Emirates, and Pakistan acknowledged it. In the late 1990s, the United Nations Security Council passed two resolutions: first urging the Taliban regime to stop treating women abusively and second, imposing sanctions on the Taliban regime for sheltering Al-Qaeda and its leaders. The Taliban refused to respond to the United Nations. In fact, in 1998, Al-Qaeda was responsible for bombing the United States embassies in East Africa. As a result, the United States accused the Taliban regime of providing a safe haven for Al-Qaeda and its leader, Osama bin Laden (Laub, 2014).

Following the terrorist attacks of September 11, 2001, the United States government declared global "War on Terrorism." The George W. Bush administration accused Al-Qaeda and the Taliban regime of harboring Al-Qaeda forces. Moreover, the Bush administration also accused many countries such as Iran, Iraq, and Syria of sponsoring and supporting terrorists. In this regard, President Bush stated that "... Syria and Iran continue to harbor and assist terrorists.... The United States lists both countries as state sponsors of terrorism because of their support for Palestinian militant groups such as Hamas and Islamic Jihad." ("Bush: Syria, Iran Harboring Terrorists," 2003). On October 7, 2001, the United States, supported by British and other NATO member forces, began its combat mission "Operation Enduring Freedom." This combat mission was intended to invade Afghanistan and topple the Taliban regime for harboring Osama bin Laden, the Al-Qaeda leader accused of the September 11, 2001, terrorist attacks on the United States.

On December 28, 2014, President Barack Obama and his Secretary of Defense, Chuck Hagel, issued concurrent statements that signified the end of combat in Afghanistan. Although this marks the end of the longest American military campaign in its history, even after 13 years, arguably there is still much work that could be done from a combat mission perspective in Afghanistan ("Obama, Hagel Mark End of Operation Enduring Freedom," 2014). However, the success, or lack thereof, of the combat missions remains debated.

Following the September 11, 2001 events, the "War on Terrorism" became a central concern of American foreign policy. The United States subsequently at- 
tacked several Islamic groups, the majority of whom are Sunni Muslims, such as Al-Shabaab in Somalia, the Taliban in Afghanistan, Al-Qaeda in Afghanistan and Iraq, Islamic State of Iraq and Syria, in order to defend its national security interests around the globe. The United States remains convinced that these Islamic groups are carrying out a radical interpretation of Islam and that they profoundly oppose the West. In addition, the United States believes those terrorist groups are posing a substantial threat to America, its allied security interests, and the entire region's stability and security.

After the Afghanistan invasion in 2001, President Bush accused Iraq of supporting terrorism. Bush claimed that there was a relationship between Iraq, Saddam Hussein, and Al-Qaeda, as well as Iraqi intelligence personnel meeting with Osama bin Laden in Sudan (Milbank, 2004). In February 2003, the George W. Bush administration developed a National Strategy for Combating Terrorism in order to counter terrorism around the world. The comprehensive plan included strategies to defeat terrorists and their organizations, to deny sponsorship, support, and sanctuary to terrorists, to minimize social and economic conditions that terrorists exploit, and to defend United States' citizens and wellbeing at home and abroad ("National Strategy for Combating Terrorism," 2003). On March 19, 2003, the United States invaded Iraq and collapsed the Saddam Hussein regime. The Bush administration accused the Iraqi regime of violating human rights, possessing WMD, and harboring terrorist leaders. Moreover, the United States' officials argued that the Iraqi regime threatened the security and stability of the entire Middle East region.

During August-September 2014, the United States formed an international coalition against ISIS. On September 23, 2014, the United States and other countries, including several Arab states (Bahrain, Jordan, Qatar, Saudi Arabia, and the United Arab Emirates), began air strikes against ISIS targets in Syria "to take out the militant group's ability to command, train and resupply its fighters" (Fantz \& Pearson, 2015).

Based on the information reviewed, it seems that the United States is concerned that if extremist Islamic militants gain control over WMD (nuclear, radiological, chemical, or biological), there would be a real threat to American national security interests, especially those in the Middle East region, perhaps leading to a rapid destabilization of the entire region.

\section{Conclusion}

This article found that the United States' economic and political presence in the Middle East region before and after World War I and after World War II aids in the understanding of how United States' presence has developed in the region and what motives were behind its presence. The current research also highlights the United States' primary interests in the Middle East including securing strategic access to oil in the Gulf region, supporting and protecting Israel's sovereignty, maintaining the United States' military bases, defending client-states 
and friendly regimes, and resisting Islamic movements and terrorist groups. On the basis of this literature review, the integration of research shows that the United States' foreign policy has continued the area critical to its national security interests due to available oil, its motivation to protect Israel, to support security by maintaining military bases, to hold the role as protectorate of client states and friendly regimes, and to resist Islamic movements and terrorist groups. These five factors are the primary motivators that have propelled American decision-makers to control the area and continue to remain important to America today. This understanding of the history of the significance of the Middle East and insight about motives and interests of American decision-makers is important to students and scholars of foreign affairs as they influence and create policy. Further, this article provides a scaffold for future studies in this field, as additional exploration and research into each of these contributing areas is warranted.

\section{References}

2015 Index of U.S. Military Strength. (n.d.). Retrieved from http://index.heritage.org/militarystrength/chapter/op-environment/middle-east/

Bush: Syria, Iran Harboring Terrorists. (2003, July 21). Retrieved from http://www.cnn.com/2003/US/07/21/bush.terror/

Carter, J. (2001). The Carter Doctrine: Third State of the Union Message, Washington, DC, January 23, 1980. In J. Podell, \& S. Anzovin (Eds.), Speeches of the American Presidents (2nd ed., p. 857). Bronx, NY: The H.W. Wilson Company.

Collin, P. H. (1998). Dictionary of Government and Politics (2nd ed., p. 50). Chicago, IL: Fitzroy Dearborn Publishers.

Cooley, A. (2008). Base Politics: Democratic Change and the U.S. Military Overseas (p. 5). Ithaca, NY: Cornell University Press.

Crabb, Jr., C. V. (1983). American Foreign Policy in the Nuclear Age (4th ed., pp. 399-400). New York, NY: Harper \& Row, Publishers, Inc.

Diller, D. C. (Ed.). (1991). The Middle East: Revised to Include a Persian Gulf Crisis Supplement (7th ed., p. 109). Washington, DC: Congressional Quarterly Inc.

Dufour, J. (2007). The Worldwide Network of US Military Bases. Global Research. http://www.globalresearch.ca/the-worldwide-network-of-us-military-bases/5564

Eisenstadt, M., \& Pollock, D. (2012). Friends with Benefits: Why the U.S.-Israeli Alliance Is Good for America. Foreign Affairs. https://www.foreignaffairs.com/articles/2012-11-07/friends-benefits

Fantz, A., \& Pearson, M. (2015). Who's Doing What in the Coalition Battle against ISIS. http://www.cnn.com/2014/10/06/world/meast/isis-coalition-nations/index.html

Fry, M. G., Goldstein, E., \& Langhorne, R. (2002). Guide to International Relations and Diplomacy (p. 9). London: Continuum.

Gelvin, J. L. (2005). The Modern Middle East: A History (pp. 247-248, 260, 214-215). New York, NY: Oxford University Press.

Hertz, E. E. (2008). The U.S. Congress in 1922. Retrieved from: http://www.mythsandfacts.org/article_view.asp?articleID $=100$

Howard, H. N. (1974). The United States and the Middle East. In T. Y. Ismael (Ed.), The Middle East in World Politics: A Study in Contemporary International Relations (pp. 
117-118). Syracuse, NY: Syracuse University Press.

Iskandar, M. (1974). The Arab Oil Question (2nd ed., pp. 33-45, 55). Beirut: Middle East Economic Consultants.

Ismael, T. Y. (1986). International Relations of the Contemporary Middle East: A Study in World Politics (pp. 135-136). Syracuse, NY: Syracuse University Press.

Jones, A. M. (1973). U.S. Foreign Policy in a Changing World (p. 184). New York, NY: David McKay Company, Inc.

Laub, Z. (2014). The Taliban in Afghanistan. Council on Foreign Relations. Retrieved from http://www.cfr.org/afghanistan/taliban-afghanistan/p10551

Lenczowski, G. (1980). The Middle East in World Affairs (4th ed., p. 792). New York, NY: Cornell University Press.

Lenczowski, G. (1984). U.S. Policy in the Middle East: Problems and Prospects. In D. L. Bark (Ed.), To Promote Peace: U.S. Foreign Policy in the Mid-1980s (pp. 163-165). Stanford, CA: Hoover Institution Press.

Little, D. (2002). American Orientalism: The United States and the Middle East since 1945 (pp. 119-120). Chapel Hill, NC: The University of North Carolina Press.

Milbank, D. (2004). Bush Defends Assertions of Iraq-Al Qaeda Relationship. Washington Post.

Military: Exercises-Central Command. (2017, February 9). Retrieved from http://www.globalsecurity.org/military/ops/ex-centcom.htm

Military: US Central Command (USCENTCOM). (2016, October 13). Retrieved from http://www.globalsecurity.org/military/agency/dod/centcom.htm

Mulhall, CSP, J. W. (1995). America and the Founding of Israel: An Investigation of the Morality of America's Role (pp. 64-65). Los Angeles, CA: Deshon Press.

National Strategy for Combating Terrorism. (2003). Retrieved from http://www.state.gov/documents/organization/60172.pdf

Obama, Hagel Mark End of Operation Enduring Freedom. (2014). Retrieved from http://www.defense.gov/news/newsarticle.aspx?id=123887

Paul, J. A. (2002). Great Power Conflict over Iraqi Oil: The World War I Era. Global Policy Forum.

https://www.globalpolicy.org/component/content/article/185-general/40479-great-pow er-conflict-over-iraqi-oil-the-world-war-i-era.html

Peretz, D. (1968). The Middle East Selected Readings (pp. 1-14). New York, NY: Houghton Mifflin Company.

Pratt, J. W. (1972). A History of United States Foreign Policy(3rd ed., p. 516). Englewood Cliffs, NJ: Prentice-Hall, Inc.

Rashid, A. (2001). Taliban: Militant Islam, Oil and Fundamentalism in Central Asia (pp. 13-18). New Haven, CT: Yale University Press.

Rustow, D. A. (1982). Oil and Turmoil: America Faces OPEC and the Middle East (pp. 92-93). New York, NY: W. W. Norton \& Company, Inc.

Sandars, C. T. (2000). America's Overseas Garrisons: The Leasehold Empire (p. 293). New York, NY: Oxford University Press Inc. https://doi.org/10.1093/acprof:oso/9780198296874.001.0001

Surratt, R. (2000). The Middle East (9th ed., p. 4). Washington DC: Congressional Quarterly Press.

Sylvan, D., \& Majeski, S. (2003). An Agent-Based Model of the Acquisition of U.S. Client 
States (pp. 1-5). Portland, OR: Paper Prepared for Presentation at the 44th Annual Convention of the International Studies Association.

The Arab-Israeli War of 1948. (n.d.). Retrieved from https://history.state.gov/milestones/1945-1952/arab-israeli-war

The Baghdad Pact (1955) and the Central Treaty Organization (CENTO). (2001-2009, January 20). Retrieved from http://2001-2009.state.gov/r/pa/ho/time/lw/98683.htm

U.S. Central Command History. (n.d.). Retrieved from http://www.centcom.mil/ABOUT-US/HISTORY/ 